\title{
MANFAAT SARI SARI KURMA DALAM MEMPERCEPAT PERSALINAN KALA 1
}

\author{
Lestari Puji astuti ${ }^{1}$, Shyntia Estika Puri ${ }^{2}$, Dita Wasthu Prasida ${ }^{3}$ \\ ${ }^{1,2,3}$ Stikes Karya Husada Semarang, Semarang, Indonesia \\ Email:tari_rozai@yahoo.co.id
}

\begin{abstract}
ABSTRAK
Persalinan yang dimulai secara spontan dalam presentasi belakang kepala pada usia kehamilan 37-42 minggu lengkap dan setelah persalinan ibu maupun bayi berada dalam kondisi sehat. Dan partus lama merupakan alasan $68 \%$ seksio sesaria non elektif pada persentasi kepala. Sementara berdasarkan kelompok umur, kejadian kematian maternal terbanyak adalah pada usia 20-34 tahun sebesar 68,50\%. Salah satu terapi nonfarmakologis untuk memicu kinerja hormone oksitosin guna mempercepat persalinan kala 1, dapat diberikan sari kurma. Yang mengandung hormone oksitosin yang akan menyebabkan kontraksi pada rahim. Tujuan dari penelitian ini adalah mengetahui pengaruh sari kurma terhadap kemajuan persalinan kala 1 fase aktif primigravida. Jenis penelitian ini menggunakan quasi eksperiment dengan desain pre test post test control grup desain . Sampel penelitian ini adalah ibu hamil 37 minggu primigravida. Subyeknya adalah 30 responden. Pengambilan data dilakukan dengan lembar observasi. Kemajuan persalinan diukur dengan lembar partograf. Penelitian ini dilakukan di RB Citra Insani pada bulan Januari 2018. Analisis bivariat menggunakan uji t-test independent dengan hasil rata-rata lama persalinan kala 1 untuk kelompok control sebesar 253,67 menit dan untuk kelompok intervensi 233,00 menit. Hasil uji $t$-test menunjukkan pvalue $=0,020$. Ada pengaruh sari kurma terhadap kemajuan persalinan kala 1 fase aktif primigravida. Ibu hamil usia 37-42 minggu dapat memanfaatkan sari kurma untuk kemajuan persalinan nonfarmakologis.
\end{abstract}

Kata Kunci: Persalinan; kala 1 fase aktif; Sari kurma;

\section{THE BENEFIT OF DATES ESSENCE ON THE PROGRESS OF LABOR IN THE $1^{\text {st }}$ PHASE OF ACTIVE PRIMIGRAVIDA}

\begin{abstract}
Spontaneous delivering process is represented by the back head is at 37-42 weeks of complete gestation and after delivering of both mother and baby are in good health. Based on the age group, the highest incidence of maternal deaths is at the age of 20-34 years of $68.50 \%$. Mothers need enough drinks and foods which contain sugar: this is because the amount of contraction of the muscles of the uterine tubes will release the baby, especially if it takes a long time. One of the non-pharmacological therapies to trigger the performance of oxytocin hormone in order to speed up labor phase 1 can be given dates essence because contains oxytocin hormone. The purpose of this study was to know the effect of date essence on the progress of labor in the $1^{\text {st }}$ phase of active primigravida. The purpose of this research was to know the influence of date essence on the progress of labor in the first phase of active primigravida. This study used quasi experiment with pre-post test design with control group design. These samples were 37 weeks primigravida pregnant. The subjects were 30 respondents. The data were collected by observation sheet. The progress of labor was measured by a partographic sheet. This research was conducted at Citra Insani Maternal Clinic in January 2018. Bivariate analysis used independent $t$-test with significance $p$ $<0,005$. Mean duration of $1^{\text {st }}$ stage labor for control group was 253,67 minutes and for intervention group was 233.00 minutes. The result of t-test shows $p$ value $=0,020$. There is the effect of date essence on the progress of labor in the $1^{\text {st }}$ phase of active primigravida. Pregnant women aged 37-42 weeks can take advantage of date essence for the advancement of non-pharmacological childbirth.
\end{abstract}

Keywords: labor progress; fist active phase; primigavida; date essence.

Jurnal SMART Kebidanan Sekolah Tinggi Ilmu Kesehatan (STIKes) Karya Husada Semarang www.stikesyahoedsmg.ac.id/ojs/index.php/sjkb 


\section{Pendahuluan}

Angka Kematian Ibu (AKI) mencerminkan risiko yang dihadapi ibu-ibu selama kehamilan sampai dengan paska persalinan yang dipengaruhi oleh status gizi ibu, keadaan sosial ekonomi, keadaan kesehatan yang kurang baik menjelang kehamilan, kejadian berbagai komplikasi pada kehamilan dan kelahiran,tersedianya dan penggunaan fasilitas pelayanan kesehatan ternasuk pelayanan prenatal dan obstetri. (Dinkes, 2015)

Persalinan dimulai dengan proses membuka dan menipisnya serviks, dan janin turun ke dalam jalan lahir. Kelahiran adalah proses dimana janin dan ketuban didorong keluar melalui jalan lahir. Proses dinamik dari persalinan meliputi empat komponen yang saling berkaitan yang mempengaruhi baik mulainya dan kemajuan persalinan. Empat komponen ini adalah passanger (janin), passage (pelvis ibu), power (kontraksi uterus), dan psikis (status emosi ibu). Bila persalinan dimulai, interaksi antara passanger, passage, power, dan psikis harus sinkron untuk terjadinya kelahiran pervaginam spontan. (oktariana, 2016)

Kemajuan persalinan pada kala I fase aktif merupakan saat yang paling melelahkan, berat, dan kebanyakan ibu mulai merasakan sakit atau nyeri, dalam fase ini kebanyakan ibu merasakan sakit yang hebat karena kegiatan rahim mulai lebih aktif. Pada fase ini, dibutuhkan kontraksi (power) yang adekuat untuk dapat memulai persalinan. Melemahnya kontraksi rahim atau kontraksi inadekuat ini merupakan penyebab terbanyak terjadinya partus lama. (oktariana, 2016)

Banyak upaya untuk mengefektifkan kontraksi (power) antara lain; teknik ambulasi, perubahan posisi, mengosongkan kandung kemih, stimulasi putting, dan pemberian nutrisi serta mengurangi stressor dan kelelahan ibu. Salah satu upaya yaitu dengan pemberian nutrisi yang baik, baik itu diberikan saat persalinan maupun sebelum persalinan.[6] Perempuan hamil yang akan melahirkan sangat membutuhkan minuman dan makanan yang kaya akan unsur gula, hal ini karena banyaknya kontraksi otot-otot rahim ketika akan mengeluarkan bayi, terlebih lagi apabila hal itu membutuhkan waktu yang lama. Kandungan gula, vitamin B1, dan zat besi sangat membantu untuk mengontrol laju gerak rahim dan menambah masa sistole (kontraksi jantung ketika darah dipompa ke pembuluh nadi). (chapman, 2013)

Sari kurma mengandung hormone potuchin yang berfungsi untuk mengikat rahim dan otot rahim sehingga dapat membantu mengurangi pendarahan pasca melahirkan. Selain itu, ada hormon oksitosin yang dapat membantu merangsang kontraksi pada otot-otot rahim 
sehingga mempermudah persalinan. Hormon ini juga akan membantu memacu kontraksi di pembuluh darah vena yang ada di sekitar payudara ibu, sehingga memacu kelenjar air susu untuk memproduksi ASI. (Khasanah, 2011)

Studi pendahuluan di Rumah Bersalin Citra Insani pada bulan Mei tahun 2017.Jumlah ib u bersalin pada bulan Mei sebanyak 42 orang, pada primigravida 25 orang dan mulrigravida 7 orang.Diperoleh hasil bahwa pembukaan serviks pada ibu primigravida kurang lebih $1,2 \mathrm{~cm}$ setiap jam. Jumlah pasien ibu bersalin yang dirujuk akibat partus tak maju sebanyak 5 orang, hal ini dikarenaka usia tidak produktif, tingkat pendidikan yang masih cukup rendah dan kelainan pada janin seperti (janin terlalu besar, lilitan tali pusat dan panggul sempit). Selama ini teknik yang digunakan untuk mempercepat persalinan berupa emotional support dengan tujuan untuk mempersiapkan psikologis ibu. Ibu yang mengalami partus lama biasanya langsung diberikan tindakan rujukan.

Berdasarkan latar belakang di atas, maka peneliti tertarik mengadakan penelitian tentang "Pengaruh Sari kurma Terhadap Kemajuan Persalinan Kala 1 Fase Aktif Primigravida di RB Citra Insani Kota Semarang”.

\section{Tinjauan Teoritis}

\section{Persalinan}

Persalinan adalah kejadian yang berakhir dengan pengeluaran bayi yang cukup bulan atau hampir cukup bulan, disusul dengan pengeluaran plasenta dan selaput janin dari tubuh ibu. Sedangkan menurut WHO persalinan normal adalah persalinan yang dimulai secara spontan (dengan kekuatan ibu sendiri dan melalui jalan lahir), beresiko rendah pada awal persalinan dan presentasi belakang kepala pada usia kehamilan antara 37-42 minggu setelah persalinan ibu maupun bayi berada dalam kondisi baik, persalinan normal disebut juga partus spontan adalah proses lahirnya bayi pada letak belakang kepala dengan tenaga ibu sendiri, tanpa bantuan alat-alat serta tidak melukai ibu dan bayi yang umumnya berlangsung kurang dari 24 jam. (oktariana, 2016)

Kala I (Kala Pembukaan) Yaitu kala pembukaan yang berlangsung antara pembukaan nol sampai pembukaan lengkap. Kala pembukaan dibagi menjadi 2 fase, yaitu :

1. Fase laten, Dimulai sejak awal kontraksi yang menyebabkan penipisan dan pembukaan serviks secara bertahap, pembukaan serviks berlangsung perlahan dari $0 \mathrm{~cm}$ sampai 3 $\mathrm{cm}$. Lama kala I untuk primigravida berlangsung 12 jam sedangkan pada multigravida sekitar 8 jam. Pada pemulaan his (kontraksi), kala pembukaan berlangsung tidak begitu Jurnal SMART Kebidanan Sekolah Tinggi Ilmu Kesehatan (STIKes) Karya Husada Semarang www.stikesyahoedsmg.ac.id/ojs/index.php/sjkb 
kuat sehingga parturient (ibu yang sedang bersalin) masih dapat berjalan-jalan untuk meminimalkan rasa sakit kontraksi.

2. Fase aktif, Kontraksi menjadi lebih kuat dan lebih sering. Fase aktif berlangsung selama 6 jam dan dibagi atas 3 sub fase :

- $\quad$ Periode akselerasi : berlangsung 2 jam dari pembukaan $3 \mathrm{~cm}$ menjadi $4 \mathrm{~cm}$.

- $\quad$ Periode dilatasi maksimal : selama 2 jam dari pembukaan $4 \mathrm{~cm}$ berlangsung cepat menjadi $9 \mathrm{~cm}$.

- $\quad$ Periode deselerasi : berlangsung lambat, dalam waktu 2 jam dari pembukaan $9 \mathrm{~cm}$ menjadi $10 \mathrm{~cm}$ atau lengkap.

Menurut Sumarah (2008), dalam satu kontraksi terjadi 3 fase, yaitu fase naik, puncak dan turun. Fase naik lamanya 2 x fase lainnya. Kontraksi uterus yang paling kuat pada fase kontraksi puncak tidak akan melebihi $40 \mathrm{mmHg}$.

Primigravida

Primigravida adalah wanita yang hamil untuk pertama kalinya, Masa kehamilan ini dimulai dari konsepsi sampai lahirnya janin. Ibu primigravida adalah seorang wanita yang pertama kali hamil. Kehamilan terjadi kalau ada pertemuan dan pertemuan antara sel telur (ovum) dan sel mani (spermatozoa). Arti hamil atau kehamilan adalah suatu keadaan dalam seseorang wanita mengandung sel telur dibuahi oleh sperma, sebagian tubuh ibu hamil tersebut mengadakan keseimbangan untuk menyesuaikan diri dengan adanya individu tersebut. (Johariyah, 2012)

2. Sari kurma

Berdasarkan kajian kimia dan fisiologi Dr Ahmad Abdul Ra'ouf Hisyam dan Dr. Ali Ahmad Syahhat, Memakan ruthab dan atau tamar ketika berbuka puasa akan menambahkan peratus kandungan glukosa dan sukrosa dalam badan.Penyakit anemia (kurang darah) akan berkurangan dan tubuh tidak pucat. Ketika perut kosong, saat itulah makanan yang mengandungi nutrien glukosa dan sukrosa akan mudah dicerna dan diserap secara cepat dan maksimum. Jadi, kandungan glukosa dan sukrosa dalam ruthab dan tamar yang banyak itu menjadikan proses mencerna dan menyerap di dalam badan sangat mudah. (Rostita, 2012)

Sari kurma adalah salah satu jenis minuman khusus yang berfungsi untuk pengobatan dan merawat kesehatan bagi tubuh. Sari kurma juga mengandung nutrisi 
yang sangat tinggi sesuai dari bahannya yaitu buah kurma. (Rostita, 2012)

Sari kurma mengandung vitamin B1 sangat membantu untuk mengontrol laju gerak rahim dan menambah masa sistolenya(kontraksi jantung ketika darah di pompa ke pembuluh nadi. Selain keduan kandungan tersebut,terdapat kandungan hormone potuchin yang berfungsi untuk mengikat rahim dan otot rahim sehingga dapat membantu mengurangi perdarahan bagi perempuan ketika melahirkan dan mempercepat proses pengembalian posisi rahim seperti sedia kala sebelum waktu hamil yang berikutnya.Karena sari sari kurma mengandung hormone yang menyerupai hormone oxytocin yang dapat membantu proses persalinan.hormon oxytocine adalah hormone yang salah satu fungsinya membantu ketika wanita melahirkan dan menyusui. (Rostita, 2012)

Kandungan gulanya sebagian besar merupakan gula monosakarida, sehingga mudah dicerna tubuh, antara lain glukosa dan fruktosa. Pada varietas sari kurma tertentu, juga terdapat gula sukrosa. Kandungan gula pada sari kurma sangat tinggi, sekitar 70 persen, yaitu 70-73 gram per 100 gram. (Satuhu, 2012)

\section{Metode Penelitian}

Penelitian ini adalah penelitian quasi eksperimen dengan rancangan pre test $n$ post test with control group test design. Responden terbagi menjadi 2 grup, grup 1 diberi beri perlakuan : pemberian sari kurma sejak umur kehamilan 37 minggu selama 4 minggu, sedangkan kelompok control hanya diberikan asuhan kebidanan standar tanpa perlakuan apa apa. Teknik pengambilan sampel menggunakan pendekatan secara accidental sampling, dimana presponden yang diambil adalah ibu hamil yang bersalin di bulan Januari 2018. dengan. kriteria sampel adalah ibu hamil primigravida yang berusia 37 minggu, kehamilan normal, dan berencana bersalin di RB Citra Insani. Penelitian di lakukan di RB Citra insane pada bulan Januari 2018. Analisa data pada penelitian ini menggunakan uji t test independen

\section{Hasil Penelitian}

Hasil penelitian menunjukkan bahwa rata-rata fase aktif pada ibu bersalin primigravida di RB Citra Insani Semarang kelompok intervensi adalah 233 menit dengan standard deviasi 21.941, pada kelompok kontrol adalah 253.67 menit dengan standard deviasi 23.865 
Sebelum dilakukan analisis data tentang pengaruh sari kurma terhadap kemajuan persalinan kala 1 fase aktif primigravida di RB Citra Insani Semarang terlebih dahulu dilakukan uji normalitas menggunakan Shapiro-wilk. untuk menentukan alat analisis data. Hasil perhitungan menggunakan uji statistik Test Independent didapatkan hasil t hitung sebesar -2.469 dengan $\mathrm{p}$ value sebesar 0.020 ( < 0.05) sehingga dapat disimpulkan ada pengaruh yang significan antara Pengaruh sari sari kurma terhadap kemajuan persalinan kala 1 fase aktif primigravida di RB Citra Insani Semarang.

\section{Pembahasan}

Berdasarkan hasil penelitian terhadap ibu hamil 37 minggu diberikan sari sari kurma di RB Citra Insani Kota Semarang tahun 2017, dengan jumlah responden 15 orang, dari hasil gambaran mengenai kemajuan persalinan kala 1 fase aktif dengan hasil rata-rata lama fase aktif terendah selama 200 menit dan lama fase aktif tertinggi 270 menit. Pada kelompok control hasil rata-rata lama fase aktif terendah selama 175 menit dan lama fase aktif tertinggi 245 menit. Hasil penelitian menunjukan persalinan kala I fase aktif didapatkan hasil t hitung sebesar -2.469 dengan $\mathrm{p}$ value sebesar $0.020(<0.05)$. Hal ini menunjukan bahwa ada pengaruh kemajuan persalinan pada kelompok eksperiment. Penelitian ini dipengaruhi oleh responden yang setuju dan patuh dalam mengkonsumsi Sari kurma untuk mengetahui pengaruhnya dalam kemajuan persalinan kala 1. Kepatuhan ini dikarenakan ruang lingkup pendidikan mereka yakni kesehatan dan rasa ingin tahu mereka untuk mengetahui efektivitas sari kurma sebagai obat non-farmakologi untuk kemajuan persalinan.

Sari Sari kurma mengandung stimulan tertentu yang memperkuat otot-otot rahim dalam beberapa bulan terakhir kehamilan. Hal ini membantu memperkuat kontraksi rahim pada saat persalinan. Sari kurma adalah buah yang kaya akan nutrisi. Di dalamnya terkandung karbohidrat, fiber, kalsium, kalium, vitamin B kompleks, magnesium, dan zat besi. Pada sari kurma kering terdapat kandungan $70 \%$ karbohidrat, sedangkan pada sari kurma basah ada kandungan 60\% karbohidrat dalam bentuk glukosa dan fruktosa. Kedua jenis gula ini tidak berbahaya karena hasil olahan alami. (Purnama sari, 2013) Glukosa dan fruktosa alami ini sangat mudah diserap oleh tubuh. Dan fungsinya adalah untuk menggantikan energi yang hilang. Itulah bagi ibu hamil, energi dari gula yang dihasilkan, bermanfaat untuk menambah kekuatan pada saat persalinan. (Rostita, 2012)

Sari kurma mengandung suatu hormon yang sering disebut dengan hormon potuchin, yang menurut para pakar medis, hormon ini berfungsi untuk mengikat rahim dan otot rahim 
sehingga dapat membantu mengurangi pendarahan pasca melahirkan. Selain itu, ada hormon oksitosin yang dapat membantu merangsang kontraksi pada otot-otot rahim sehingga mempermudah persalinan. Hormon ini juga akan membantu memacu kontraksi di pembuluh darah vena yang ada di sekitar payudara ibu, sehingga memacu kelenjar air susu untuk memproduksi ASI. (Satuhu, 2012)

Hasil penelitian ini sesuai dengan penelitian yang dilakukan oleh Arman Sitohang ${ }^{[10]}$ dengan judul pengaruh pemberian sari sari kurma terhadap kadar hormone kortisol tikus putih betina di akhir kehamilan dengan hasil penelitian ada hasil significant pada tikus putih betina yang diberikan sari sari kurma. Sedangkan, pada kelompok control dengan hasil rata-rata fase aktif terendah 210 menit dan lama fase aktif tertinggi 285 menit aktif terendah 210 menit dan lama fase aktif tertinggi 285 menit.

Hasil penelitian ini sesuai dengan teori bahwa Pada primigravida dalam rangkaian kasus Friedman, lama rata-rata fase aktif adalah 5,8 jam dan batas normal sebelah atasnya adalah 12 jam. Kecepatan dilatasi cervik berkisar dari 1,2 hingga 6,8 cm perjam. Bagi seorang ibu hamil ketika menjelang persalinan cenderung mengalami rasa cemas jika rasa cemas ini berlebihan maka dapat mengakibatkan partus lama. Hasil penelitian ini sesuai dengan penelitian yang dilakukan Nur Masruroh $^{[10]}$ dengan judul pengaruh kecemasan ibu terhadap proses persalinan kala 1 fase aktif di BpS Atik Suharijati Surabaya dengan hasil penelitian menunjukkan hampir setengahnya (41.7\%) mengalami cemas ringan dan sebagian besar responden (75 \%) mengalami fase aktif $<6$ jam. Hasil uji statistik didapatkan $p=0,024<\alpha=0,05$.

\section{Kesimpulan}

Ada pengaruh pemberian sari kurma terhadap kemajuan persalinan kala 1 fase aktif primigravida di RB Citra Insani Semarang.

\section{Saran}

1. Bagi tenaga kesehatan (Bidan khususnya ) di Rumah Bersalin Kota Semarang

Bidan diharapkan dapat mempromosikan sari kurma kepada ibu hamil mulai dari 37 minggu untuk memperlancarkan kemajuan persalinan.

2. Bagi peneliti

Mengingat keterbatasan peneliti dalam mengambil sampel sebagai obyek yang diteliti, diharapkan para peneliti selanjutnya lebih memperbanyak pada jumlah sampel yang akan 
diteliti sehingga akan diperoleh skala keputusan yang berbeda yang mendukung hasil penelitian.

\section{Daftar Pustaka}

Chapman, v. (2013). persalinan dan kelahiran asuhan kebidanan. jakarta.

Damayanti, I. (2014). buku ajar asuhan kebidanan komprehensif pada ibu bersalin dan bayi baru lahir. yogyakarta.

Dinkes. (2015). Profil Kesehatan. Jawa Tengah.

Johariyah, e. w. (2012). asuhan kebidanan persalinan dan bayi baru lahir. jakarta.

Khasanah, n. (2011). kandungan buah buahan dalam Al Quran untuk kesehatan. jurnal phenomenon, 5-29.

Oktariana, M. (2016). [2] buku ajar asuhan kebidanan persalinan dan bayi baru lahir. yogyakarta.

Purnama sari, s. d. (2013). pengaruh sari sari kurma terhadap waktu perdarahan pada tikus jantan galur wistar yang di induksi aspirin , 20.

Rostita. (2012). khasiat dan keajaiban sari kurma. bandung.

Satuhu, s. (2012). sari kurma khasiat dan aneka olahannya. depok. 